\title{
THE CYTOPROTECTIVE ACTIVITY OF AQUEOUS GREEN TEA EXTRACT AGAINST METRONIDAZOLE AND TINIDAZOLE GENOTOXIC EFFECT
}

\author{
ALI FARIS HASSAN ${ }^{*}$, MAHMOOD KAHTAN ${ }^{1}$, NADA NAJE AL-SHAWI ${ }^{1}$, INTESAR TAREQ NUMAN ${ }^{2}$, \\ GHAITH ABBAS BAHADER ${ }^{3}$
}

\begin{abstract}
${ }^{1}$ Department of Pharmacology and Toxicology, College of Pharmacy, University of Baghdad, Baghdad, Iraq. ${ }^{2}$ Department of Pharmacology and Toxicology, College of Pharmacy, University of AL-Bayan, Baghdad, Iraq. ${ }^{3}$ Department of Pharmaceutical Chemistry, College of Pharmacy, University of Baghdad, Baghdad, Iraq. Email: ali_1371982@yahoo.com
\end{abstract}

\begin{abstract}
Received: 22 October 2018, Revised and Accepted: 26 November 2018
ABSTRACT

Objective: The study was designed to evaluate the genoprotective effect of green tea extract against genotoxicity induced by metronidazole and tinidazole.

Methods: A total of 36 mice were used, for each experiment. The animals were allocated into six groups: Group I - negative control administered distilled water; Group II - healthy mice treated with metronidazole alone, Group III - healthy mice treated with tinidazole alone, Group IV - healthy mice administered green tea extract alone, Group V - healthy mice administered of metronidazole anddd then green tea extract was administered, and Group VI - healthy mice administered of tinidazole and then green tea extract was administered.
\end{abstract}

Results: It has been found that there are significant differences in mitotic index and micronucleus (MN) appearance between the Groups II, IV, and V $(7.76 \pm 0.8,11.92 \pm 1.14$, and $8.36 \pm 0.57$ and $6.92 \pm 0.5,10.18 \pm 1.19$, and $7.52 \pm 1.05)$ in bone marrow cells and spleen cells for mitotic index, respectively $(6.75 \pm 0.4,5.5 \pm 0.41$, and 5.92 \pm 0.68$)$, in bone marrow for MN appearance. Furthermore, it has been found that there are significant differences in mitotic index and MN appearance between the Groups III, IV, and VI (4.36 $\pm 0.88,11.92 \pm 1.14$, and 5.36 \pm 0.55 and 4.08 $\pm 0.35,10.18 \pm 1.19$, and 5.08 \pm 0.35$)$ in bone marrow cells and spleen cells for mitotic index, respectively (8.43 $\pm 0.96,5.5 \pm 0.41$, and $6.84 \pm 0.66)$, in bone marrow for MN appearance.

Conclusion: The aqueous extract of green tea has a protective effect against the genotoxic effects induced by either metronidazole or tinidazole in mice.

Keywords: Green tea, Metronidazole, Micronucleus, Mitotic index, Tinidazole.

(C) 2019 The Authors. Published by Innovare Academic Sciences Pvt Ltd. This is an open access article under the CC BY license (http://creativecommons. org/licenses/by/4. 0/) DOI: http://dx.doi.org/10.22159/ajpcr.2019.v12i1.30363

\section{INTRODUCTION}

Human exposure to different types of chemical substances, some of these chemical substances are cytotoxic in nature like antineoplastic medications, cytotoxicity in these medications is a major pharmacological action against cancerous cells $[1,2]$. Other medications have cytotoxicity as an adverse effect. Nowadays many approaches have been used to minimize this adverse effect without need to withdrawal these medications from the market [3] one of these approaches is the using of plants extracts. Some of these extracts have the ability to decrease the cytotoxicity to a significant level; these substances are considered as cytoprotective agents [4].

The in vitro and in vivo micronucleus (MN) assay is used for the detection of any chemical compound which may induce the formation MN which is a small membrane-bound DNA fragment. These micronuclei maybe originate either when chromosome fragments lacking a centromere or when whole chromosomes are unable to migrate with the rest of the chromosomes during the anaphase of cell division [5,6]. Metronidazole is antiprotozoal medication. It is used to treat many pathological conditions such as endocarditis, bacterial vaginosis, giardiasis, trichomoniasis, and amebiasis [7,8]. Metronidazole and its metabolites disrupted DNA integrity besides it interacts with cellular components, leading to cell death $[9,10]$. Tinidazole is an antiparasitic drug clinically use against amoebae, giardia, and trichomonas [11]. Authors have been utilized human cell lines to study the effect of tinidazole on cell division and they reported that the intended drug may possess genotoxic effect on the cell division [12]. Camellia sinensis (green tea) have many therapeutic benefit effects. Its leaves have been known to contain active ingredients such as polyphenols (catechins), caffeine (called theine), tannin (flavonols), theophylline, theobromine, saponins, essential oils, carotene, and many vitamins and trace elements and others [13]. The health benefits include the prevention of cancer and cardiovascular diseases besides it have the anti-inflammatory, anti-arthritic, antibacterial, antiangiogenic, antioxidative, antiviral, neuroprotective, and cholesterol-lowering effects [14]. This study was designed to evaluate the protective effect of aqueous green tea extract against a genotoxic effect of two antiprotozoal medications (metronidazole and tinidazole) in bone marrow cells and spleen cells.

\section{METHODS}

Plants collection

The plant was brought from the Iraqi market and authenticated by the Department of Pharmacognosy and Medicinal plants, College of the Pharmacy, University of Baghdad. A voucher sample was kept at the Department of Pharmacognosy and Medicinal plants, College of the Pharmacy, University of Baghdad.

\section{Extraction}

Powdered plant material (200 g) was taken in a conical flask and extracted with $500 \mathrm{ml}$ of distilled water (DW) with a mechanical shaker with temperature control (room temperature) at the constant stirring rate at $200 \mathrm{rpm}$. It was left for $24 \mathrm{~h}$, and solids were filtered using Whitman No. 1 filter. The extraction was repeated 3 times until complete extraction [15]. 
Phytochemical investigation

A preliminary phytochemical investigation was carried out for all fractions using the following tests [16].

\section{Test for alkaloids}

About $20 \mathrm{mg}$ of each fraction was mixed in $2 \mathrm{ml}$ of $1 \% \mathrm{HCl}$, warmed, and filtered, and the filtrate was treated separately with both reagents (Mayer's and Dragendorff's). Detection whether the alkaloids were present or not is through the formation of turbidity or precipitate.

\section{Test for saponins}

Few milligrams from each fraction were dissolved in boiling water in a test tube, cooled, and shaken vigorously to form a stable, persistent froth.

\section{Test for flavonoids}

Few milligrams of each fraction were shaken with hexane, filtered, and dissolved in $3 \mathrm{ml}$ of $80 \%$ ethanol and filtered. The filtrate was used for the following tests:

a. $1 \mathrm{ml}$ of the filtrate was mixed with $1 \mathrm{ml}$ of $1 \%$ aluminum chloride in methanol in a test tube. Formation of yellow color indicated the presence of flavonoids.

b. $1 \mathrm{ml}$ of the filtrate was mixed with $1 \mathrm{ml}$ of dilute ammonium hydroxide solution. A dark yellow color indicated the presence of flavonoids.

\section{Test for phenols}

$1 \mathrm{ml}$ from each fraction was treated separately with $1 \%$ ferric chloride solution in a test tube. The formation of deep green-blue color indicates the presence of phenolic compounds.

\section{Test for methylxanthine}

Caffeine reacts with the excess accurately known amount of iodine in an acidic environment, forming an insoluble precipitate.

\section{Test for volatile oils}

Dried leaves were collected and subjected to hydrodistillation for $3 \mathrm{~h}$ using a Clevenger-type apparatus.

\section{Animals}

Animals were purchased from the Animal House of the College of Pharmacy, Baghdad University. 36 albino Swiss mice for each of mitotic index and MN assay, weighing 23-27 g, were used in this study in accordance to the guidelines of the Biochemical and Research Ethical Committee at College of Pharmacy, University of Baghdad. Animals housed for 2 days under standard conditions (temperature $22 \pm 2^{\circ} \mathrm{C}$, relative humidity $50-60 \%$, and $12 \mathrm{~h}$ day and night cycle). Food consisted of normal animal chow and water was provided ad libitum. All experimental procedures were performed from 8 to $10 \mathrm{a} . \mathrm{m}$. For each experiment, the animals were allocated into six groups ( 6 mice each) and treated as follows: Group I - negative control (orally administered DW) for 7 consecutive days; Group II - healthy mice treated with metronidazole alone at dose $78 \mathrm{mg} / \mathrm{kg}$ orally once daily for 10 consecutive days; Group III - healthy mice treated with tinidazole alone at dose $52 \mathrm{mg} / \mathrm{kg}$ orally once daily for 10 consecutive days; Group IV - healthy mice orally administered aqueous green tea extract (1.25\%) alone for 7 consecutive days; and Group V - healthy mice orally administered of metronidazole (78 mg/kg) for 10 days. At the day 11,1.25\% aqueous extract of green tea was orally administered once daily for 7 consecutive days; and Group VI - healthy mice orally administered of tinidazole $(52 \mathrm{mg} / \mathrm{kg})$ for 10 days. At the day $11,1.25 \%$ aqueous extract of green tea was orally administered once daily for 7 consecutive days. The aqueous green tea extract at $1.25 \%$ concentration was administered to mice in Groups II, V, and VI as their sole source of drinking water.

Evaluation of genotoxicity in bone marrow cells and spleen cells At the end of the experiment, each animal utilized in the present study was intraperitoneally injected with $1 \mathrm{mg} / \mathrm{kg}$ colchicine, and after $2 \mathrm{~h}$, they were sacrificed by cervical dislocation. Bone marrow samples were aspirated from the femur bone and processed using an aseptic technique for evaluation of mitotic index as previously reported elsewhere [17].

\section{MN test}

Mice were sacrificed by spinal dislocation at the end of the experiment. Bone marrow smears were prepared as described by Agarwal and Chauhan [18], stained with Giemsa, and the calculating incidence of micronuclei appearance.

\section{Statistical analysis}

Data were expressed as mean \pm standard deviation. Statistical analyses were performed using unpaired Student $t$-test. If the overall $\mathrm{F}$ value was found statistically significant $(\mathrm{p}<0.05)$, further comparisons among groups were made according to post hoc Tukey's test. All statistical analyses were performed using SPSS 20.

\section{RESULTS}

\section{Phytochemical results}

In Table 1. phytochemical investigations that done on the green tea extract showed that there were different active constituents that present in this extract, these active constituents include saponins, polyphenols, volatile oil and flavonoids.

Table 2 shows that mitotic index in both bone marrow cells and spleen cells did not significantly differ in metronidazole-treated mice (78 mg/kg) (Group II) compared to negative control animals ( $p>0.05$ ); however, in tinidazole ( $52 \mathrm{mg} / \mathrm{kg}$ )-treated animals (Group III), there was a significant reduction in mitotic index compared to negative control animals in both bone marrow cells and spleen cells $(\mathrm{p}<0.05)$. Besides, the aqueous extract of green tea at a concentration (1.25\%) (Group IV) produced a significant elevation in mitotic index in both bone marrow cells and spleen cells when compared to negative control mice $(\mathrm{p}<0.05)$.

Furthermore, Table 2 shows that there are significant differences in mitotic index among three different group (metronidazole-treated group, aqueous green tea extract group, and metronidazole plus aqueous green tea extract group) in bone marrow cells and spleen cells $(p<0.05)$. Furthermore, there are significant differences among the groups (tinidazole group, aqueous green tea extract, and tinidazole plus aqueous green tea extract) in mitotic index in bone marrow cells and spleen cells $(\mathrm{p}<0.05)$.

In Table 3, there was a non-significant difference in the MN appearance in metronidazole-treated group (Group II) (78 mg/kg) when compared to negative control in bone marrow cells $(p>0.05)$, but there was a significant elevation in the appearance of MN in tinidazole-treated group of mice (Group III) (52 mg/kg) when compared to negative controls in bone marrow cells $(p<0.05)$. Moreover, Table 2 shows that the aqueous extract of green tea at a concentration (1.25\%) (Group IV) produced a significant reduction in the MN appearance in bone marrow cells compared to negative control mice $(\mathrm{p}<0.05)$.

In addition, in Table 3, there are significant differences $(\mathrm{p}<0.05)$ in the incidence of MN appearance among the groups (metronidazole group, aqueous green tea extract group, and metronidazole plus aqueous green tea extract group) in bone marrow cells $(6.75 \pm 0.4,5.5 \pm 0.41$, and $5.92 \pm 0.68$, respectively); furthermore, there are significant differences $(\mathrm{p}<0.05)$ in the incidence of MN appearance among the groups (tinidazole group, aqueous green tea extract, and tinidazole plus

\section{Table 1: Phytochemical investigation of Camellia sinensis (green tea)}

\begin{tabular}{ll}
\hline Type of test & Results \\
\hline Test for alkaloids & Negative \\
Test for saponin & Positive \\
Test for flavonoids & Positive \\
Test for volatile oil & Positive \\
Test for methylxanthine & Positive \\
Test for phenol & Positive \\
\hline
\end{tabular}


Table 2: Effects of $1.25 \%$ concentration of aqueous green tea extract on metronidazole $(78 \mathrm{mg} / \mathrm{kg})$ and tinidazole $(52 \mathrm{mg} / \mathrm{kg}) \mathrm{on}$ a mitotic index in both bone marrow cells and spleen cells in mice

\begin{tabular}{|c|c|c|c|}
\hline Number of groups & Names of groups & Bone marrow cells & Spleen cells \\
\hline I & Water (negative control) & $8.68 \pm 0.44$ & $7.12 \pm 0.27$ \\
\hline II & Metronidazole at dose $78 \mathrm{mg} / \mathrm{kg}$ & $7.76 \pm 0.84^{\mathrm{A}}$ & $6.92 \pm 0.53^{\mathrm{A}}$ \\
\hline III & Tinidazole at dose $52 \mathrm{mg} / \mathrm{kg}$ & $4.36 \pm 0.88^{* a}$ & $4.08 \pm 0.35^{* a}$ \\
\hline IV & Aqueous green tea extract $1.25 \%$ & $11.92 \pm 1.14^{* \mathrm{Bb}}$ & $10.18 \pm 1.19 * \mathrm{Bb}$ \\
\hline V & Metronidazole $(78 \mathrm{mg} / \mathrm{kg})+$ green tea extract $1.25 \%$ & $8.36 \pm 0.57^{\mathrm{C}}$ & $7.52 \pm 1.05^{\mathrm{C}}$ \\
\hline VI & Tinidazole $(52 \mathrm{mg} / \mathrm{kg})+$ green tea extract $1.25 \%$ & $5.36 \pm 0.55^{c}$ & $5.08 \pm 0.35^{c}$ \\
\hline
\end{tabular}

Data expressed as mean \pm SD; $n=6$ animals in each group. *Significant difference compared to the negative control group (p<0.05); values with non-identical small letters superscripts ( $\mathrm{a}, \mathrm{b}$, and $\mathrm{c}$ ) are considered significantly different $(\mathrm{p}<0.05)$ among Groups (III, IV, and VI). Values with non-identical capital letters superscripts (A, B, and C) are considered significantly different $(\mathrm{p}<0.05)$ among Groups (II, V and VI). SD: Standard deviation

Table 3: Effects of $1.25 \%$ concentration of aqueous green tea extract on metronidazole-treated $(78 \mathrm{mg} / \mathrm{kg})$ and tinidazole-treated $(52 \mathrm{mg} / \mathrm{kg})$ groups on $\mathrm{MN}$ appearance in bone marrow cells in mice

\begin{tabular}{lll}
\hline Groups & Names of groups & Bone marrow cells \\
\hline I & Water (negative control ) & $6.67 \pm 0.42$ \\
II & Metronidazole at dose $78 \mathrm{mg} / \mathrm{kg}$ & $6.75 \pm 0.4^{\mathrm{A}}$ \\
III & Tinidazole at dose $52 \mathrm{mg} / \mathrm{kg}$ & $8.34 \pm 0.96^{* \mathrm{a}}$ \\
IV & Aqueous green tea extract 1.25\% & $5.5 \pm 0.41^{* \mathrm{Bb}}$ \\
V & Metronidazole $(78 \mathrm{mg} / \mathrm{kg})+$ green tea extract $1.25 \%$ & $5.92 \pm 0.68^{\mathrm{C}}$ \\
VI & Tinidazole (52 mg/kg)+green tea extract 1.25\% & $6.84 \pm 0.66^{\mathrm{c}}$ \\
\hline
\end{tabular}

Data are expressed as mean \pm SD; $n=6$ animals in each group; *significantly different compared to negative control ( $p<0.05$ ); Values with non-identical small letter superscripts ( $\mathrm{a}, \mathrm{b}$, and c) are considered significantly different among Groups (III, IV, and VI) ( $<<0.05)$. Values with non-identical capital letter superscripts (A, B, and C) are considered significantly different among Groups (II, IV, and V ( $<<0.05)$. MN: Micronucleus, SD: Standard deviation

aqueous green tea extract) in bone marrow cells $(8.34 \pm 0.96,5.5 \pm 0.41$, and $6.84 \pm 0.66$, respectively).

\section{DISCUSSION}

In the present study, it has been found that mitotic index of bone marrow cells and spleen cells significantly increases after the administration of green tea extract in groups that administered metronidazole or tinidazole previously when compared to the groups the administered metronidazole and tinidazole alone. MN appearance has been significantly decreased after administration of green tea extract in groups that administered metronidazole or tinidazole previously when compared to the groups the administered metronidazole and tinidazole alone.

Metronidazole and tinidazole considered as a first choice in the treatment of protozoa infections, and at the same time, these two medications have different adverse effects to make them unable to be used for a prolonged period. One of these unwanted effects is the cytotoxicity. Metronidazole has been reported to be cytotoxic in different studies [19]. Similarly, it has been reported that tinidazole possesses genotoxic which lead to either induce DNA repair system or induce apoptosis. The induction of DNA repair system leads to a decrease in cell division [12]. Plant materials rich in phenolics are increasingly being used in the food industry because they retard oxidative degradation of lipids and improve the quality and nutritional value of food. Phenolic compounds are considered secondary metabolites, and these phytochemical compounds derived from phenylalanine and tyrosine occur ubiquitously in plants and are diversified. Green tea may have a wide variety of pharmacological activity due to the presence of huge different types of active ingredients; thus, it is nowadays widely used for its health properties [20]. In the present study, the use of metronidazole and tinidazole for 10 successive days produced a decrease in cell proliferation and increase the incidence if MN appearance, but oral administration of $1.25 \%$ concentration of aqueous green tea extract for 7 successive days after the use of metronidazole or tinidazole group produced a significant increase in the cell proliferation with decrease in the MN appearance. Hydroxyl radical is one of the powerful reactive oxygen species in the biological system. Hydroxyl radical reacts with a polyunsaturated fatty acid of cell membrane phospholipids and causes harm to the cell. Moreover, the hydroxyl radical is considered a harmful species in pathophysiological processes and capable of damaging every molecule of the biological system and contributes to carcinogenesis, mutagenesis, and cytotoxicity [21]. The data of this study showed that there are a significant amount of flavonoids and alkaloids, as many previous studies have shown that flavonoid and related polyphenols contribute significantly to the phosphomolybdate scavenging activity of medicinal plants [22]. The proposed mechanism of action may be scavenging through the hydroxyl radicals and prevent the degradation of 2-deoxyribose [23,24]. There are two major restrictions in the present manuscript, first one is the need of extensive phytochemical investigations to identify, purification and separation of active constituents, the second restriction is related to the dose and duration of administration of metronidazole and tinidazole, the use of more than one dose and extending in the duration of administration give us a more clear picture for the protective effect of green tea.

The recommendation for further work in manifested by using different dose and/or duration of metronidazole and tinidazole administration.

\section{ACKNOWLEDGMENTS}

The authors thank the College of the Pharmacy, University of Baghdad for supporting the project.

\section{AUTHORS' CONTRIBUTIONS}

The first author performed the procedure and wrote manuscripts. The second author guided through the procedure, and third and fourth author discuss the final results. Fifth author help in performing the procedure. All authors are responsible for financial support to complete the research.

\section{CONFLICTS OF INTEREST}

There are no conflicts of interest.

\section{REFERENCES}

1. Hoose SA, Duran C, Malik I, Eslamfam S, Shasserre SC, Downing SS, et al. Systematic analysis of cell cycle effects of common drugs leads to the discovery of a suppressive interaction between gemfibrozil and fluoxetine. PLoS One 2012;7:e36503.

2. Stępnik M, Spryszyńska S, Gorzkiewicz A, Ferlińska M. Cytotoxicity of anticancer drugs and PJ-34 (poly(ADP-ribose)polymerase-1 
(PARP-1) inhibitor) on HL-60 and jurkat cells. Adv Clin Exp Med 2017;26:379-85

3. So WW, Liu WN, Leung KN. Omega-3 polyunsaturated fatty acids trigger cell cycle arrest and induce apoptosis in human neuroblastoma LA-N-1 cells. Nutrients 2015;7:6956-73.

4. Dhuna K, Dhuna V, Bhatia G, Singh J, Kamboj SS. Cytoprotective effect of methanolic extract of Nardostachys jatamansi against hydrogen peroxide induced oxidative damage in C6 glioma cells. Acta Biochim Pol 2013;60:21-31.

5. Hayashi M. The micronucleus test-most widely used in vivo genotoxicity test. Genes Environ 2016;38:18.

6. Fenech M. The micronucleus assay determination of chromosomal level DNA damage. Methods Mol Biol 2008;410:185-216.

7. Löfmark S, Edlund C, Nord CE. Metronidazole is still the drug of choice for treatment of anaerobic infections. Clin Infect Dis 2010;50 Suppl 1:S16-23.

8. Gerding DN, Muto CA, Owens RC Jr. Treatment of clostridium difficile infection. Clin Infect Dis 2008;46 Suppl 1:S32-42.

9. Müller M. Mode of action of metronidazole on anaerobic bacteria and Protozoa. Surgery 1983;93:165-71.

10. Uzlikova M, Nohynkova E. The effect of metronidazole on the cell cycle and DNA in metronidazole-susceptible and-resistant giardia cell lines. Mol Biochem Parasitol 2014 198:75-81.

11. Armstrong NR, Wilson JD. Tinidazole in the treatment of bacterial vaginosis. Int J Womens Health 2010;1:59-65.

12. López Nigro MM, Carballo MA. Genotoxicity and cell death induced by tinidazole (TNZ). Toxicol Lett 2008;180:46-52.

13. Ragaa S, Alaa SA, Mohammed AA, Ayman AG, Amira AA. Determination of phenolic components and antioxidant activity of some Egyptian tea samples. Int J Pharm Pharm Sci 2015;7:198-202.
14. Chacko SM, Thambi PT, Kuttan R, Nishigaki I. Beneficial effects of green tea: A literature review. Chin Med 2010;5:13.

15. Okoduwa SI, Umar IA, James DB, Inuwa HM, Habila JD. Evaluation of extraction protocols for anti-diabetic phytochemical substances from medicinal plants. World J Diabetes 2016;7:605-14.

16. Chandrashekar K, Santanu S, Prasanna K. Phytochemical studies of aerial parts of the plant Leucas lavandulaefolia. Der Pharma Chem 2010;2:434-7.

17. Allen JW, Shuler CF, Mendes RW, Latt SA. A simplified technique for in vivo analysis of sister-chromatid exchanges using 5-bromodeoxyuridine tablets. Cytogenet Cell Genet 1977;18:231-7.

18. Agarwal DK, Chauhan LK. An improved chemical substitute for fetal calf serum for the micronucleus test. Biotech Histochem 1993;68:187-8.

19. Carballo MA, Palermo AM, Mudry MD. Toxicogenetic evaluation of metronidazole in the treatment of women infected with Trichomonas vaginalis. Ann Trop Med Parasitol 2004;98:139-47.

20. Izzreen MN, Fadzelly AB. Phytochemicals and antioxidant properties of different parts of Camellia sinensis leave from Sabah tea plantation in Sabah, Malaysia. Int Food Res J 2013;20:307-12.

21. Dizdaroglu M, Jaruga P. Mechanisms of free radical-induced damage to DNA. Free Radic Res 2012;46:382-419.

22. Zubeyir H, Sukru B, Ilhami G. Antioxidant and antiradical properties of selected flavonoids and phenolic compounds. Biochem Res Int 2017;2017:10.

23. Prakash NK, Ranjithkumar M, Sripriya N, Lakshmi R, Deepa S, Bhuvaneswar S. Antioxidant, free radical scavenging activity and GCMS studies on Pedilanthus tithymaloides (L.) poit. Int J Pharm Pharm Sci 2014;6:284-7.

24. Fahim MM, Hayder BS, Khalid WQ. B2 agonist salbutamol modulates skin wound healing processes. Int J Res Pharm Sci 2018;9:37-45. 